\title{
Global market integration, efficiency orientation, and drivers of foreign subsidiary divestments
}

Citation for published version (APA):

Belderbos, R., De Michiel, F., Sleuwaegen, L., \& Wu, S. (2021). Global market integration, efficiency orientation, and drivers of foreign subsidiary divestments. Journal of World Business, 56(5), [101228]. https://doi.org/10.1016/j.jwb.2021.101228

Document status and date:

Published: 01/08/2021

DOI:

10.1016/j.jwb.2021.101228

Document Version:

Publisher's PDF, also known as Version of record

Document license:

Taverne

Please check the document version of this publication:

- A submitted manuscript is the version of the article upon submission and before peer-review. There can be important differences between the submitted version and the official published version of record.

People interested in the research are advised to contact the author for the final version of the publication, or visit the DOI to the publisher's website.

- The final author version and the galley proof are versions of the publication after peer review.

- The final published version features the final layout of the paper including the volume, issue and page numbers.

Link to publication

\footnotetext{
General rights rights.

- You may freely distribute the URL identifying the publication in the public portal. please follow below link for the End User Agreement:

www.umlib.nl/taverne-license

Take down policy

If you believe that this document breaches copyright please contact us at:

repository@maastrichtuniversity.nl

providing details and we will investigate your claim.
}

Copyright and moral rights for the publications made accessible in the public portal are retained by the authors and/or other copyright owners and it is a condition of accessing publications that users recognise and abide by the legal requirements associated with these

- Users may download and print one copy of any publication from the public portal for the purpose of private study or research.

- You may not further distribute the material or use it for any profit-making activity or commercial gain

If the publication is distributed under the terms of Article $25 \mathrm{fa}$ of the Dutch Copyright Act, indicated by the "Taverne" license above, 


\title{
Global market integration, efficiency orientation, and drivers of foreign subsidiary divestments
}

\author{
René Belderbos $^{\mathrm{a}, \mathrm{b}, \mathrm{c}}$, Federico De Michiel ${ }^{\mathrm{d}}$, Leo Sleuwaegen ${ }^{\mathrm{a}, \mathrm{e}}$, Shubin Wu ${ }^{\mathrm{f}, *}$ \\ ${ }^{a}$ Department of Management, Strategy and Innovation, Faculty of Economics and Business, KU Leuven, Naamsestraat 69, B-3000 Leuven, Belgium \\ ${ }^{\mathrm{b}}$ UNU-MERIT, Maastricht, The Netherlands \\ ${ }^{\mathrm{c}}$ Department of Organization, Strategy and Entrepreneurship, School of Business and Economics, Maastricht University, Maastricht, The Netherlands \\ ${ }^{\mathrm{d}}$ Copenhagen Economics, Maison de la Radio, Place Eugène Flagey 18, BE-1050, Brussels, Belgium \\ e Vlerick Business School, Belgium \\ ${ }^{\mathrm{f}}$ University of Liverpool Management School, University of Liverpool, Chatham Street, Liverpool L69 7ZH, United Kingdom
}

\section{A R T I C L E I N F O}

\section{Keywords:}

Affiliate divestment

Global industry integration

Responsiveness

Global strategy

Efficiency

\begin{abstract}
A B S T R A C T
Differences in global market integration across industries have important repercussions for MNC strategy and the drivers of manufacturing subsidiary divestment decisions. Global industry integration and the associated competitive pressures lead MNCs to adopt cost efficiency strategies for their subsidiary networks, and subsidiary divestment decisions are strongly driven by labor cost considerations. In non-integrated industries, host country demand conditions are the prime driver of divestments. These patterns are the most salient for MNCs that have aligned their strategy with the global industry environment. Analysis of the divestment hazards of 3827 Japanese manufacturing subsidiaries in $\mathbf{5 7}$ countries provides support for these conjectures.
\end{abstract}

\section{Introduction}

The vast body of literature on multinational corporations (MNCs) has primarily studied the strategic implications of firms' international expansion: the different motives and modes of entry in foreign markets (e.g. Dunning, 2009; Brouthers and Hennart, 2007), factors determining location choices (e.g. Belderbos, Du and Slangen, 2020; Head, Ries, and Swenson, 1995; Belderbos and Sleuwaegen, 2005) and the relationship between internationalization and performance (e.g. Kim et al.,2015; Delios and Beamish, 1999; Belderbos, Tong and Wu, 2014). In contrast, much less effort has been devoted to understanding the (strategic) reasons and contingencies explaining why firms retrench by divesting foreign subsidiaries (e.g. Boddewyn, 1979; McDermott, 2010; Schmid and Morschett 2020; Iurkov and Benito 2018; Tan and Sousa, 2018).

The choice to divest, via assets sell-off to a third party or closure of plants abroad, is a complex phenomenon (Mata and Portugal, 2000; Benito, 1997; Schmid and Morschett, 2020) and reliable information on divestments is not always made available by companies because of their association with failure. Previous studies have recognized poor performance, both at the firm and subsidiary level to be correlated with divestments (e.g. Berry, 2013; Duhaime and Grant, 1984; Markides, 1992;
Pennings and Sleuwaegen, 2000). Foreign subsidiary divestments have also been found to depend on the mode of entry (e.g. Li, 1995; Mata and Portugal, 2000; Gaur and Lu, 2007; Makino and Beamish, 1998; Belderbos and Zou, 2009), the purposes of the investment (Getachew and Beamish, 2017), the relatedness with the company's core business (Tan and Sousa, 2018; Berry, 2013; Li, 1995; Duhaime and Grant, 1984; Ogasavara and Hoshino, 2008) and the firm's prior international experience (e.g. Benito, 1997; Shaver et al., 1997; Li, 1995; Kim, Lu and Rhee, 2012; Iurkov and Benito, 2018).

Host country environmental conditions have also been shown to affect divestment decisions. Firms are more likely to divest subsidiaries in host countries with negative growth prospects (Benito, 1997; Delios and Beamish, 1999; Konara and Ganotakis, 2020; Song, 2015), increased factor costs (Belderbos and Zou, 2009; Pennings and Sleuwaegen, 2000), institutional instability and deteriorated policy environments (Henisz and Delios, 2001; Dhanaraj and Beamish, 2004; Tan and Sousa, 2018; Blake and Moschieri, 2017; Dai, Eden and Beamish, 2017) and asymmetries with political freedom or other institutions in the home country (Soule et al., 2014; Gaur and Lu, 2007).

The expanding literature on foreign divestment has given surprisingly little attention to changes in the global environment in the industries

\footnotetext{
* Corresponding author.

E-mail addresses: rene.belderbos@kuleuven.be (R. Belderbos), fdm@copenhageneconomics.com (F. De Michiel), leo.sleuwaegen@kuleuven.be (L. Sleuwaegen), wushubin@liverpool.ac.uk (S. Wu).
} 
in which MNCs operate, and the related strategic orientation of MNCs (Benito, 2005). Prior literature has noted that in a number of industries, such as electronics and textiles, global liberalization and the associated falling trade barriers (Krueger, 1995) in conjunction with declining transportation and communication costs and convergence in consumer demands (Hummels, 1999) have spurred the development of globally integrated markets. Such markets are characterized by intensified competition and cost and efficiency pressures, pushing MNCs to adopt global efficiency strategies (Johansson and Yip, 1994; Kobrin, 1991; Morrison and Roth, 1992; Birkinshaw et al., 1995) and to locate manufacturing activities for the world market in the best locations (Krugman, 1980; Porter, 1986; Yip, 1989). In other industries, such as the food industry, world markets remain largely fragmented due to heterogeneous consumer preferences and host country regulations. MNCs competing in such industries are more likely to adopt local responsiveness strategies to cater to heterogeneous consumer demands (Ghoshal, 1987; Birkinshaw et al., 1995; Bartlett and Ghoshal, 1989). While the responses of MNCs to global integration in terms of adjusting their international strategy in an increasingly interconnected world have been well documented (Hennart, 2007; Kim \& Aguilera, 2015; Wiersema \& Bowen, 2008), the consequences for divestment behavior have not received due attention.

In this study, we argue that divergent industry trends in global market integration lead MNCs to adapt their strategy and the organization of their global manufacturing subsidiary networks, with important consequences for the drivers of subsidiary divestments. In globally integrated industries, MNCs are under greater pressure to optimize their subsidiary networks for cost efficiency, which leads to a greater focus on (labor) cost reduction, and a stronger divestment response to high local labor costs. In contrast, in industries that are on a less pronounced global integration path, local market conditions remain important and are also the prime driver of MNCs' decisions on divestments or survival of subsidiaries. Since heterogeneities in strategic approaches among MNCs remain present due to idiosyncratic firm-specific resources and capabilities, the strength of MNCs' responses to global changes can differ (Harzing, 2000; Bartlett \& Ghoshal, 1989; Birkinshaw et al., 1995), such that these patterns are most pronounced for MNCs that have aligned their international strategic orientation with the global industry environment. Hence, the role of key drivers of foreign affiliate divestments, labor cost and demand, will crucially depend on the state of the global industry and the MNCs' strategic responses to global industry changes.

We test our predictions on a comprehensive panel dataset of 3827 manufacturing subsidiaries of 650 Japanese firms established in 57 countries during a period in which major changes in global industry integration occurred, 1990-2004. We follow previous studies on industry globalization (Wiersema and Bowen, 2008; Morrison and Roth, 1992; Chang and Rhee, 2011) by measuring (changing) global industry integration as the degree to which the global industry is exposed to import competition (Babones, 2008).

We contribute to the subsidiary divestment literature by bringing in the role of (changing) global industry conditions and related MNC strategy into the conceptual framework of subsidiary, parent firm, and host country drivers of divestments. We show that the impact of known host country drivers of divestment exhibits salient heterogeneity depending on the nature of the global industry environment. Hence, we contribute the notion that subsidiary investment decisions should be seen in the context of broader MNC strategies (Benito, 2005) aimed at alignment with the global environment. This contrasts with prior studies, which have limited attention to subsidiary characteristics, host country factors or parent firm traits (e.g. Berry, 2013; Mata \& Portugal, 2000; Benito, 1997; Li, 1995; Fang et al., 2013; Tan and Sousa, 2018), without considering subsidiaries as part of MNCs that strategically respond to changing global business conditions (Wiersema \& Bowen, 2008). Hence, we answer to the call in a recent review of the literature to give proper attention to MNCs' strategic considerations behind divestment decisions (Schmid and Morschett, 2020). In doing so, our study also contributes to existing research on global industry integration and the associated firm responses (Kobrin, 1991; Wiersema and Bowen, 2008; Morrison and Roth, 1992; Chang and Rhee, 2011;) by taking into account how global industry forces shape the fate of individual subsidiaries in their local environment.

Our paper contributes to a stream of research relying on rich data on Japanese affiliates and their survival drawn from Toyo Keizai Inc., Directory of Japanese Foreign Affiliates, a source frequently used in prior research on foreign investment and divestment (e.g. Ogasavara and Hoshino 2008; Dhanaraj and Beamish 2004; Delios and Beamish 2001; Kim, Lu and Rhee 2012, Dai, Eden and Beamish 2017; Getachew and Beamish 2017; Gaur and Lu 2007, Fang et. al, 2013; Fang et al., 2007; Belderbos, Tong and Wu, 2014). Our paper advances this stream of research by introducing a novel theoretical perspective: we argue and demonstrate how the divestment decisions related to two major drivers, demand conditions and labor costs, are jointly shaped by the interplay of the global industry environment and the strategic orientation of the multinational firm. We hope that our work draws renewed attention to the important impact of macroeconomic conditions (on a global scale) on firms' divestment decisions.

\section{Background and hypotheses}

We first review prior research on divestments, which has focused on parent firm, subsidiary, and host country drivers. Subsequently, we posit the role of the global industry environment as an important additional factor, and argue that differences between developments in this industry environment alter the importance of host country drivers of divestments.

\section{Background: determinants of subsidiary divestments}

Research on divestments and relocations of MNCs' subsidiaries is still relatively scarce, but the attention given to these phenomena has significantly increased over time (McDermott, 2010; Schmid and Morschett, 2020). Prior research has grouped drivers of divestment decisions at the level of the parent firm and its multinational network, at the level of the individual subsidiary, and at the level of the host country (e.g. Delios and Beamish, 2001; Li, 1995; Mata and Portugal, 2000; Berry, 2013). were found to

At the parent level, profitability, size and experience were found to influence the decision to divest foreign subsidiaries. Financially distressed firms are under more pressure and more likely to make divestment decisions (Haynes et al. 2003; Iurkov and Benito, 2018). A mitigating effect of parent size on the probability of foreign divestment has been associated with the resource-based view of the firm. A large parent firm can support its foreign subsidiaries with more and different types of resources helping them to survive (Belderbos and Zou 2009; Dhanaraj and Beamish, 2004; Song and Lee, 2017; Getaschew and Beamish, 2017). Similarly, experience of the parent helps to avoid mistakes and find better solutions when subsidiaries are confronted with adverse shocks (Benito 1997; Norback et al. 2015; Song 2015; Kim, Lu and Rhee, 2012; Fang et al., 2007; Tan and Sousa, 2018; Ogasavara and Hoshino, 2008).

With a focus on the multinational network, recent work taking a real option perspective has suggested that firms may be reluctant to divest under uncertainty, in particular if the subsidiary has a platform function in the host country and contributes to network flexibility by increasing the options for production shifting (Belderbos and Zou, 2009). In contrast, firms with an extended manufacturing network may face lower barriers to exit as they are less dependent on any single foreign production operation (Bernard and Jensen, 2007; Berry, 2013). Faced with the fixed cost of relocation, financially stronger firms carry out divestment decisions more easily and are found to profit more from the relocation of businesses units (Pennings and Sleuwaegen, 2000; Belderbos and Zhu, 2007). In line with the literature on the liability of foreignness, 
previous experience of the firm in the host country is found to reduce the probability of subsidiary divestment, as MNCs that are acquainted with the host country business environment and local partners are better able to deal with unexpected local developments (Li, 1995; Shaver et al., 1997; Zaheer, 1995). Other studies emphasize inter-subsidiary competition within the network and find the risk of divestment or contraction of the subsidiary to be greater if the MNC made investments in other parts of its foreign network (e.g. Norback, Tekin-Koru, and Waldkirch, 2015; Dörrenbächer and Gammelgaard, 2010). Iurkov and Benito (2018) in this context emphasize the domestic network of the MNC and find a higher risk of foreign operations being divested when parent firm operations become more central in its domestic network of strategic alliances.

At the level of the subsidiary, poor performance is empirically shown to be a strong predictor of divestment decisions (Duhaime and Grant, 1984; Markides, 1992). Subsidiaries unrelated to the firm's core business activities are more likely to be divested (e.g. Chang and Singh, 1999; Doukas and Lang, 2003; Li, 1995; Berry, 2013; Benito, 1997) as the firm's core intangible resources cannot be shared or are not directly transferable to the subsidiary (Tan and Sousa, 2018; Berry, 2013). Other empirical research has found a positive relationship between the size of the foreign subsidiary and its survival, as large sunk cost investments deter firms from exiting the market (Belderbos and Zou, 2009; Chen and Wu, 1996; Li, 1995; Mata and Portugal, 2000). Similarly, important investments in location-specific human capital deter subsidiary divestment (Mata and Portugal, 2000; Song and Lee, 2017). In addition, the mode of entry and ownership structure influence subsidiaries' chances to survive. Acquisitions and joint ventures experience higher divestment hazards than greenfield investments and fully owned subsidiaries because of the difficulties in coordinating with investment partners or agreeing on shared objectives (Li, 1995; Mata and Portugal, 2000; Berry, 2013; Makino and Beamish, 1998; Dhanaraj and Beamish, 2004).

At the level of the host country, the probability of divestment is lower when local demand in the country is growing (Benito, 1997; Shaver et al., 1997; Konara and Ganotakis, 2020; Song, 2015). High or rising labor costs in the host country, on the other hand, undermine profitability and reduce the chances of survival of subsidiaries (Belderbos and Zou, 2009; Pennings and Sleuwaegen, 2000). Research has also found that multinational firms maintain their operations in countries with stable institutions (Henisz and Delios, 2001; Benito, 1997; Tan and Sousa, 2018), a favorable political environment (Blake and Moschieri, 2017), and similar levels of freedom and transparency as in the home country (Soule et al., 2014). Getachew and Beamish (2017) show in the context of Japanese affiliates in Africa that the influence of institutional voids on divestments depends on the subsidiaries' investment purposes and market orientation.

\section{The role of the global industry environment}

We argue that, in addition to the extensive set of divestment drivers identified in the literature, the global industry context is likely to have a profound impact on the decision to divest, by altering the importance of key drivers of divestments. Global economic liberalization and deregulation have led to the integration of markets across countries. During the last decades, the world has witnessed a progressive fall in tariff and nontariff restrictions. Whereas in the past, national technical standards as well as trade restrictions such as import tariffs, quotas and local content requirements imposed by local governments prevented firms from selling their products abroad or forced firms to manufacture locally in foreign markets (Doz, 1987; Belderbos and Sleuwaegen, 1998; 2005), the gradual removal of various kinds of trade and investment barriers in several industries has strongly stimulated trade across countries and spurred the global integration of markets and supply chains. This internationalization process has been greatly facilitated by advances in information and communication technologies and the drastic reduction in logistics costs. This process accelerated in the early nineties of last century until the start of the financial crisis in the year 2007, after which the integration process lost momentum.

The growing openness to trade has introduced strong competition in the industries affected by it. Competition from firms based in other countries introduces diverse and less familiar capabilities into an industry, creating a more dynamic and uncertain competitive environment (Wiersema and Bowen, 2008, Ghoshal, 1987; Chang and Rhee, 2011) and strengthening the role that large global firms play in shaping global competition. There is substantial evidence showing that the rise in international competition led to restructuring of firms and industries. Industry-level studies demonstrate significant effects on prices, market shares and exit of domestic firms due to increased foreign competition in domestic markets (e.g., Melitz and Ottaviano, 2008). The marked growth in trade coming from low cost countries particularly has had consequences. Bernard et al. (2007) show that increased trade from low cost countries led to an upgrading and reallocation of activities toward high value activities in US firms. Coucke et al. (2008) find that import competition from low cost countries exerted a strong impact on the exit of firms in the EU. In industries subject to global and intensified competition, firms face strong pressures to operate efficiently by aiming to benefit from scale economies and to reduce costs by concentrating production in low cost locations. This process tends to be associated with increasing standardization of products and process and the organization of global supply chains (Lu and Jiang, 2017).

Not all industries have become equally global, and levels of global competition can differ substantially across industries (Wiersema and Bowen, 2008; Morrison and Roth, 1992). Industries that serve universal needs with standard products such as equipment, machinery, computers, and electronics were among the first to become globalized (Bartlett and Ghoshal, 1989; Kobrin, 1991; Morrison and Roth, 1992). In other industries, such as the food industry, standardization has had much less potential due to remaining differences in tastes and culture. In such industries, country centered strategies focusing on the need to suit local demand patterns and to exploit localized resources remain common (Birkinshaw, Morrison and Hullan, 1995; Johansson and Yip, 1994).

We argue that the differences in competitive forces and pressures for efficiency in integrated versus non-integrated industries are likely to exert a profound effect on firms' international strategy and the motives of the divestments of subsidiaries by MNCs resulting in different behavioral regimes' of divestments in globally integrated versus nonintegrated industries. Given this dichotomy, firms competing in integrated industries are expected to operate different subsidiary networks and to respond differently to host country divestment drivers, but their precise responses will also depend on the degree to which the firms have aligned their international strategy with global industry conditions. Below we formulate hypotheses about these behavioral differences, which we put to test using divestment data from Japanese MNCs.

\section{Hypotheses}

Global industry integration not only widens the relevant market in which firms compete, but also creates opportunities for firms to integrate and co-ordinate their activities across countries. The globalization of relevant markets implies that the competitive arena for firms widens and that competitive pressures increase, with more firms participating from diverse countries. This increased competitive pressure in turn forces firms to improve their efficiency.

Competition through globalization drives the standardization of demand across countries due to global quality standards, an increased transfer of information across borders, and the spread of global media (Levitt, 1983; Belk, 1996). In global industries in which demand converges towards homogeneous products, MNCs can implement a global marketing strategy (Zou and Cavusgil, 2002; Hultman et al., 2009; Schmid and Kotulla, 2011) and standardize their product offerings, promotional mix and pricing across geographic markets. The more 
uniform response pattern of customers around the world allows MNCs to adopt effective global strategies that target different markets without the need to adapt products and services to local conditions. Global integration rather than local responsiveness becomes the focus of MNC strategy (Bartlett and Ghoshal, 1989; Prahalad and Doz, 1987).

In integrated industries characterized by standardization and global competition, firms do not need to operate manufacturing activities in each market, as there are limited benefits of producing close to customers. Instead, they can develop an integrated network of subsidiaries, with manufacturing operations focusing on exports in a limited number of locations to exploit differential comparative advantages of countries (Porter, 1986; Dunning, 1980). Competition related to globalization is a main channel through which MNCs adapt business units' and subsidiaries' strategies, which Kobrin (1991) defines as 'rationalization that may entail standardization of products, centralization of technological development, or the vertical or horizontal integration of manufacturing'. Firms aim to achieve cost efficiency by manufacturing their products in subsidiaries located in countries where production costs are low, and exporting from there to international markets through their global distribution network (Harzing, 2000; Birkinshaw et. al., 1995; Johansson and Yip, 1994). Hence, subsidiaries in MNCs' production network often produce for global markets and focus on cost reduction. A key focus by MNCs is on the reduction in labor costs, as labor is the most immobile production factor for MNCs in host countries and determines much of the comparative advantage of production locations (Birkinshaw at al., 19951; Hanson et al. 2005). Whilst there are fewer opportunities to reduce labor costs, MNCs have a much more flexible choice in using global or local supply chains, and if other input costs change locally, they can substitute the input for imports from other countries, in particular in globally integrated industries (e.g. Rangan, 1998). Previous work has therefore confirmed that divestments and relocations are highly sensitive to labor costs (e.g. Belderbos and Zou, 2009; Pennings and Sleuwaegen, 2000; Hanson et al., 2005).

In contrast, in non-integrated industries, firms are driven to adopt country localization strategies and develop activities close to their markets. This has advantages when firms encounter substantial cultural, economic and regulatory differences across countries. Subsidiaries of firms with a market localization strategy tend to focus on serving their local market, with relatively strong autonomy from headquarters and the international network of the MNC. The gains from such a strategy derive from a better response to local needs in different markets. While this might penalize the global efficiency of the firm as it incurs duplication costs of managing a constellation of independent subsidiaries, there is less pressure on cost efficiency in non-integrated industries, and margins can be maintained through a dedicated offering to the local market and a higher willingness to pay (Bartlett and Ghoshal, 1989; Porter, 1986). This local responsiveness building on subsidiary specific resources and capabilities tends to come at a cost of giving up some integration benefits but is the best response in such environments (Prahalad and Doz, 1987).

Studies on the impact of global market integration on the strategies and organizational structure of MNCs have emphasized the importance of an alignment between the environment in which the firm operates and the firm's strategy and corresponding organizational architecture (Rugman et al., 2011). There are strong benefits of strategic alignment with environmental conditions leading to a convergence trend towards a restricted number of optimal strategic positions in the same industry (e. g. Short et al., 2007). While firms in less integrated and more fragmented industries maintain country localization strategies and operate subsidiaries focusing on local demand conditions, in industries with high levels of global integration, firms are under pressure to adopt global efficiency strategies, with subsidiaries in their network focusing on labor costs and exports. We hypothesize:

Hypothesis 1: In industries with high levels of global industry integration, firms are more likely to adopt an efficiency orientation in their network of subsidiaries.
The arguments above have direct consequences for the host country drives of subsidiary divestments. If, due to global integration, differences across geographic markets level off and the advantages of localization strategies in which products are tailored for the local market become less important, the relationship between the subsidiary and local market demand becomes weaker. Instead, firms face pressures to focus on efficiency and to organize their network of subsidiary activities to take advantage of locations with the lowest costs. This stimulates the divestment of subsidiaries in countries where wage costs are high (Belderbos and Zou, 2007; Pennings and Sleuwaegen, 2000). Hence, in integrated industries subsidiary divestments will be more responsive to host country labor costs and less responsive to host country market conditions. In fragmented, non-integrated industries, in contrast, where products are adapted to the local market and cannot easily be traded, subsidiary operations are dependent on local market developments and divestments will be more responsive to (a lack of) local market prospects rather than local labor costs. This leads to the following hypotheses:

Hypothesis 2: In industries with high levels of global industry integration, the positive relationship between host country labor cost and subsidiary divestment is more pronounced.

Hypothesis 3: In industries with low levels of global industry integration, the negative relationship between host country demand conditions and subsidiary divestment is more pronounced.

Although MNCs are likely to respond to global integration and adjust their international strategies in an increasingly interconnected world (Hennart, 2007; Porter, 1986; Yip, 1989; Kim \& Aguilera, 2015; Wiersema \& Bowen, 2008), heterogeneities in strategic approaches among MNCs can remain present. The literature on the resource-based view of the firm recognizes the firm as a unique mix of resources and competencies, which will orient the firm's (international) expansion in particular directions (Grant, 1991). Firms also differ in terms of the organizational capabilities they build over time through learning processes at various hierarchical levels within the company (Teece et al., 1997; Nelson, 1991; Belderbos and Grimpe, 2020). Once organizational resources and capabilities are developed in the context of a given strategy, this 'administrative heritage' may lead to path dependence, an increase in the costs of strategic adjustment, and reduced responsiveness to changes in the industry environment (e.g. Collis, 1991; Leonard Barton, 1992). Heterogeneity can also relate to different managerial mindsets and heterogeneous governance structures(Nadkarni et al., 2011).

Hence, there can still be variation in international strategies across firms within an industry due to firms' and subsidiaries' unique bundles of resources and capabilities. In the specific context of MNCs, studies have emphasized the differentiated and evolving subsidiary roles (e.g. Bartlett and Ghoshal, 1989; Hood and Young, 1987). Subsidiaries may be heterogeneously positioned to focus on efficient utilization of country specific advantages. MNCs with strong subsidiaries may become more dependent on local sources of knowledge and firm specific advantages in comparison to headquarter resources and home country related advantages (Scott-Kennel and Giroud, 2015). Even in industries in which there is pressure for cost efficiency, subsidiaries of MNCs may partially pursue demand oriented strategies due to a unique set of resources and capabilities allowing them to develop product quality or niche strategies (e.g. Porter, 1986).

Due to these heterogeneities in subsidiary and MNC resources and capabilities, differences in the degree of alignment of MNCs' international strategy with the global industry environment will exist. These will affect MNCs' divestment behavior. MNCs with a clear alignment of their strategy with global industry conditions are expected to show the most salient pattern of divestment drivers, with labor cost of prime importance in integrated industries and host market demand dominant in unintegrated industries. In contrast, MNCs that have not adopted a pronounced efficiency oriented strategy in a globally integrated industry, and MNCs that have not adopted a localization strategy in a fragmented industry, are less likely to show a strong relationship 
between divestment and labor cost or host country demand, respectively. This suggest the following hypotheses:

Hypothesis 4: In industries with high levels of global integration, the strongest positive relationship between host country labor cost and subsidiary divestment holds for MNCs with a pronounced strategic orientation towards efficiency (rather than localization).

Hypothesis 5: In industries with low levels of global integration, the strongest negative relationship between host country demand conditions and subsidiary divestment holds for MNCs with a pronounced strategic orientation towards localization (rather than efficiency).

\section{Data and methods}

We follow Ahlstrom, Bruton and Zhao (2013) and discuss and describe the sample of firms and affiliates used in this study first, after which we present variables and methods. Foreign subsidiary data were obtained from different editions of the Directory of Overseas Affiliates, published by Toyo Keizai, Inc. Toyo Keizai data are based on the responses of annual surveys sent to general managers and subsidiary managers of Japanese firms. This database provides detailed information on the subsidiary's location, date of establishment, industry, firm ownership, the number of employees, and investment purpose of the subsidiary. Firm financial information was taken from the Development Bank of Japan, which provides financial statements of all firms listed on Japanese stock exchanges. Divestment cases of foreign subsidiaries were identified by comparing the yearly information on affiliates in the Toyo Keizai dataset and from a separate list of divested subsidiaries made available by Toyo Keizai.

We select all publicly listed Japanese manufacturing firms and their manufacturing subsidiaries. We restrict the analysis to MNCs with at least two active manufacturing subsidiaries for two reasons. First, this selection MNCs guarantees a minimum level of multinationality to allow identification of their efficiency strategy. Second, this selection can help avoid that a potential divestment decision would lead to the special situation that the firm ceases to be a multinational firm (in terms of overseas manufacturing presence).

Consistent with prior research, we consider only subsidiaries in which the firm has at least a $10 \%$ equity stake. Subsidiaries owned by more than one Japanese firm are assigned to each of the investors. This results in a panel of 3827 subsidiaries owned by 650 manufacturing firms active in 57 different countries and 13 (2-digit) industries over the period 1990-2004. The resulting dataset comprises a total of 29205 subsidiary-year observations and includes 654 divestments. This implies a divestment rate of $17 \%$ over the period. The sample provides ample variation across industries and time, and covers the years when globalization was rising to its strongest level. An extension beyond the covered period would have to deal with the 2007 financial crisis that may temporarily have altered relationships of interest.

The systematic documentation of foreign affiliates of Japanese multinational firms by Toyo Keizai Inc. has inspired many researchers to address issues in international business, including the survival/divestment or performance of affiliates ( e.g. Makino and Beamish, 1998; Ogasavara and Hoshino 2008; Dhanaraj and Beamish 2004; Delios and Beamish 2001; Kim, Lu and Rhee 2012; Dai, Eden and Beamish 2017, Getachew and Beamish 2017; Gaur and Lu 2007; Fang et al. 2013; Fang et al., 2007). Three novelties and improvements in our data construction and methods are worth noting. First, we make extensive use of confirmed divestment lists separately published by Toyo Keiza, Inc. This has the advantage of avoiding false positive divestment when affiliates disappear for one or more years from the lists but re-appear later (a problem that can occur if research only relies on the yearly affiliate listings). Second, we exploit information on global affiliate motivations to construct a strategy orientation indicator at the parent firm. The role of strategic considerations and motivation has not been given due attention in divestment research before (Schmid and Morschett, 2020). The studies of Makino, Chan, Isobe, and Beamish (2007) who explicitly examined the effects of investment motivation at startup on the termination of international joint ventures, and Getachew and Beamish (2017) who included affiliate investment motivations in a study of divestments of African affiliates of Japanese firms are partial exceptions. Third, we combine parent and affiliate level data with external information on global industry conditions to create substantial new insights into MNCs' divestment behavior.

Tables 1 and 2 present, respectively, the distribution of subsidiaries and divestments across countries and across industries. The largest number of subsidiaries is located in China (23\%), followed by the US (14\%) and Thailand (11\%), while Western EU countries account for ten percent of the subsidiaries in the sample. During the observation period, almost one fourth of all manufacturing subsidiary divestments (156) took place in the US, for a divestment rate of $29 \%$. Japanese manufacturing subsidiaries in EU countries experienced a similar divestment rate (27\%). On the other hand, divestment rates in China and South-East Asian countries such as Thailand were lower, $7 \%$ and $10 \%$, respectively.

In terms of the distribution across over industries, Table 2 shows that subsidiaries manufacturing electrical and general machinery, transport equipment, and chemical products account for sixty four percent of the sample, with the remainder active in food, textiles, ceramic products and precision instruments, among others. Table 2 also shows the total number of observations on subsidiaries in these industries in the analysis, and the number of observations in which the industry is characterized by high or low global industry integration. Six industries, electric machinery, transport machinery, chemicals, general machinery, textiles and precision instruments (representing jointly more than eighty percent of sample observations) switch from low to high global integration during the observation period. Global industry integration is low in food, fabricated metals, rubber, paper and printing and iron and steel. The only industry with consistently high global integration is nonferrous metals.

\section{Variables}

Table 1

Distribution of subsidiaries by country/region.

\begin{tabular}{llll}
\hline Country/Region & \#Subsidiaries & \#Divestments & Divestment ratio. \\
\hline China & 866 & 57 & 7 \\
US & 531 & 156 & 29 \\
Thailand & 416 & 41 & 10 \\
EU & 364 & 100 & 27 \\
Taiwan & 277 & 50 & 18 \\
Malaysia & 226 & 30 & 13 \\
Indonesia & 222 & 18 & 8 \\
Korea & 215 & 50 & 23 \\
Singapore & 132 & 28 & 21 \\
Philippines & 117 & 15 & 13 \\
India & 83 & 9 & 11 \\
Brazil & 81 & 26 & 32 \\
Canada & 48 & 18 & 38 \\
Mexico & 44 & 14 & 32 \\
Hong Kong & 42 & 3 & 7 \\
Australia & 41 & 15 & 37 \\
Czech Republic & 18 & 0 & 0 \\
Hungary & 15 & 2 & 13 \\
Pakistan & 11 & 3 & 27 \\
Poland & 8 & 0 & 0 \\
Rest of World & 70 & 19 & 27 \\
Total & $\mathbf{3 8 2 7}$ & $\mathbf{6 5 4}$ & $\mathbf{1 7 \%}$ \\
\hline
\end{tabular}

Our first dependent variable is the efficiency orientation of the MNC's 
Table 2

Distribution of subsidiaries, divestments, and sample observations by industry and high vs. low Global Industry Integration (GII) regime.

\begin{tabular}{|c|c|c|c|c|c|}
\hline Industry & \#Subsidiaries & \#Divestments & Observations Full sample & Observations Low GII & Observations High GII \\
\hline Electric Machinery & 972 & 219 & 8020 & 2326 & 5694 \\
\hline Transport Equipment & 761 & 93 & 5512 & 3489 & 2023 \\
\hline Chemicals & 596 & 90 & 4340 & 2644 & 1696 \\
\hline General Machinery & 468 & 67 & 3435 & 888 & 2547 \\
\hline Food & 186 & 40 & 1646 & 1646 & 0 \\
\hline Textiles & 170 & 40 & 1305 & 242 & 1063 \\
\hline Ceramics & 134 & 20 & 1065 & 1065 & 0 \\
\hline Non-ferrous Metals & 118 & 22 & 838 & 0 & 838 \\
\hline Precision Instruments & 114 & 17 & 853 & 262 & 591 \\
\hline Fabricated Metals & 101 & 16 & 683 & 683 & 0 \\
\hline Rubber Products & 76 & 8 & 603 & 603 & 0 \\
\hline Paper \& Printing & 69 & 12 & 509 & 509 & 0 \\
\hline Iron \& steel & 62 & 10 & 396 & 396 & 0 \\
\hline Total & 3827 & 654 & 29205 & 14753 & 14452 \\
\hline
\end{tabular}

global subsidiary network. We derive efficiency orientation by utilizing information on the purpose of the MNC's subsidiaries reported in the Toyo Keizai survey. ${ }^{1}$ If a subsidiary lists labor cost or export to a third country as its primary motivation, we take this as evidence of an efficiency strategy focusing on cost reduction and the global specialization of production. This is because firms with an efficiency orientation will operate subsidiaries focusing on labor cost reduction, and will engage in intra-firm and export trade to serve global markets from these specialized manufacturing locations (e.g. Harzing, 2000; Birkinshaw et. al., 1995; Johansson and Yip, 1994; Kobrin, 1991). In contrast, if the firm follows a localization strategy in the host countries in which it operates to cater to idiosyncratic local demand, its affiliates are much less likely to engage in exports to other markets (Rugman et al., 2011; Harzing, 2000). Efficiency orientation is measured for an MNC in each year as the share of the MNC's manufacturing subsidiaries reporting labor cost or export to third countries as motivations. On average, about fifteen percent of manufacturing affiliates of the MNCs have such motivations

Table 3

Descriptive Statistics.

\begin{tabular}{lllll}
\hline Variable & Mean & Std. Dev. & Min & Max \\
\hline Divestment & 0.022 & 0.148 & 0 & 1 \\
Global industry integration & 0.335 & 0.122 & 0.081 & 0.652 \\
Firm efficiency orientation & 0.148 & 0.138 & 0 & 1 \\
Labor cost & 0.920 & 0.872 & 0.007 & 5.230 \\
Demand growth & 5.178 & 3.234 & -9.750 & 13.762 \\
Japanese agglomeration & 3.685 & 1.221 & 0 & 6.043 \\
RCA & 0.683 & 0.362 & 0.006 & 2.346 \\
Market Uncertainty & 0.057 & 0.073 & 0 & 0.571 \\
Political risk & 0.327 & 0.206 & 0 & 0.720 \\
Transport infrastructure & 0.001 & 0.003 & 0 & 0.092 \\
Trade openness & 0.968 & 0.921 & 0.144 & 3.828 \\
Age subsidiary & 11.613 & 9.326 & 1 & 69.000 \\
Minority owned & 0.331 & 0.471 & 0 & 1 \\
Subsidiary size & 5.182 & 1.508 & 0 & 11.156 \\
Unique subsidiary & 0.544 & 0.498 & 0 & 1 \\
Sales co-location & 0.265 & 0.441 & 0 & 1 \\
R\&D co-location & 0.048 & 0.213 & 0 & 1 \\
HQ co-location & 0.067 & 0.250 & 0 & 1 \\
Firm experience & 27.597 & 11.316 & 0 & 69.000 \\
Firm diversification & 2.285 & 1.593 & 1 & 10.000 \\
ROA & 0.014 & 0.026 & -0.109 & 0.104 \\
Firm resource intensity & 0.200 & 0.089 & 0.013 & 0.646 \\
Firm size & 19.564 & 1.653 & 14.416 & 23.816 \\
Industry contraction & 0.351 & 0.477 & 0 & 1 \\
\hline
\end{tabular}

\footnotetext{
${ }^{1}$ We note that information on subsidiary purpose is not available for each subsidiary, but at the parent firm level the coverage is sufficient to derive a measure of efficiency orientation at the MNC level.
}

(see Table 3 below). We test Hypothesis 1 by regressing the MNC's efficiency orientation on the global industry integration level of the industry in which the MNC is active.

The second dependent variable, subsidiary divestment, is a binary variable that takes the value 1 in year $t$ when a foreign manufacturing subsidiary is divested by its firm via plant closure or asset sell-off. As we observe subsidiaries from 1990 to 2004, observations on surviving subsidiaries are right censored in 2004. Since we are interested in the divestment decision of subsidiaries as a response to, among others, the host country environment, we do not include divestments due to the sale, closure, or delisting of the parent firm in Japan. In such cases, we consider the observations to be right censored in the year that we no longer observe the firm.

\section{Focal independent variables}

Global industry integration is computed at the industry-year level as the penetration of imports in the industry in world markets (the ratio of global imports over global production). This measure captures the degree of exposure to imports and hence the intensity of global competition due to the falling of trade barriers and globalization of markets (Wiersema and Bowen, 2008; Arribas et al., 2009). This measure of globalization has been central in extant work in international business and strategy (Wiersema and Bowen, 2008; Chang and Rhee, 2011). The measure has been used by the OECD and the World Bank, and is the most widely used measure for globalization (Babones, 2008). Annual data on world industry production and imports are taken from the CEPII TradeProd database (de Sousa et al., 2012), which extends the "Trade, Production and Protection" dataset of the World Bank (Nicita and Olarreaga, 2007). The TradeProd dataset contains industry data at the 2-digit Industry Standard Industrial Classification (ISIC) Revision 2 level - which can be matched with the industry classification in the Toyo Keizai data.

The variable labor cost is the monthly manufacturing wage in the host country of the subsidiary expressed in 1000 dollars. Data on labor costs (denominated in local currencies) are obtained from the International Labor Organization's Labor Statistics Database. The data are then converted into dollars using exchange rate information obtained from the United Nation's National Accounts Main Aggregates Database-Exchange Rates and Population. Host country demand conditions are reflected in the variable demand growth, calculated as the moving average of real GDP growth rate in the preceding three years using information from the Penn World Tables 8.1 (Konara and Ganotakis, 2020; Berry, 2013; Song, 2015; Benito, 1997). ${ }^{2}$ While the size of the market is

\footnotetext{
${ }^{2}$ We note that industry-specific local demand indicators would be preferable (e.g. Li, 1995; Konara and Ganotakis, 2020), but these are not available for our large set of observations at the country-industry-year level.
} 
considered to be an important factor to attract foreign investment (Dunning, 1980), once the subsidiary is established, the ability of the country to remain attractive will depend on the presence of growth or decline in local demand. We test Hypotheses 2-4 by examining whether the effects of labor cost and demand growth are different for firms operating in integrated and non-integrated (fragmented) industries, which we explain in more details in the methods section.

\section{Control variables}

We include a comprehensive set of control variables at the host country, firm, subsidiary, and industry level that have been suggested by previous studies to influence foreign subsidiary divestment decisions. At the host country level, we include market uncertainty. As divestments are costly and irreversible, highly volatile contexts present an option value in maintaining a subsidiary. The higher the uncertainty, the more firms may postpone their decision to withdraw until more information is revealed (Kogut and Kulatilaka, 1994; Belderbos and Zou, 2009; Chung et al., 2013). To construct market uncertainty we regress host country GDP on time for the past five years and use the obtained root mean square error of the regression scaled by the value of GDP to arrive at a standardized proxy of market uncertainty for each host country and year (e.g., Kogut, 1991; Li \& Li, 2010).

We control for the host country's the logarithm of Revealed Comparative Advantage (RCA), the ratio between the share of host country export in the focal subsidiary's industry $i$ over total host country export and the share of that industry in worldwide industry export. Prior studies also suggest that firms try to avoid politically and institutionally unstable countries (Delios and Henisz, 2003; Berry, 2013). We control for this potential factor by incorporating Henisz's (2000) measure of political risk. To account for possible agglomeration externalities and the availability of related suppliers due to the presence of other Japanese investors in the same host country, we include Japan agglomeration - the number (in logarithm) of Japanese manufacturing subsidiaries located in the host country and active in the same industry as the focal subsidiary (Chung and Song, 2004; Belderbos and Zou, 2009; Belderbos and Carree, 2002; Head, Ries and Swenson, 1995). Finally, the analysis controls for two variables measuring the infrastructure and policy environment for trade. Trade openness is the ratio between the sum of exports and imports to GDP for the host country, and transport infrastructure is the investment in transportation infrastructure scaled by GDP. For both variables, information is taken from the Penn World Tables 9.1.

The models include a set of factors at the subsidiary level that are likely to influence its survival. Subsidiary size, the number of employees of the subsidiary (in logarithm), has been shown to be negatively correlated with divestment (e.g. Mata and Portugal, 2000; Li, 1995; Fang et al., 2007). We include both the linear and squared term of subsidiary age to allow for a more complex relationship between subsidiary survival and age (Belderbos and Zou, 2009; Li, 1995; Mata and Portugal, 2000; Dhanaraj and Beamish, 2004). Previous studies suggest that subsidiaries jointly owned are more likely to be divested (Dhanaraj and Beamish, 2004; Hennart et al., 1998; Li, 1995; Berry, 2013; Makino and Beamish, 1998) because of higher risks of disagreement with local partners and the easier withdrawal due to the lower financial commitment. We add a dummy variable minority owned that takes value 1 if the firm holds a minority stake (less than $50 \%$ ) in the subsidiary. We also include a dummy variable unique subsidiary that takes the value 1 if the subsidiary is the only manufacturing subsidiary owned by the firm in the focal country and industry. Firms are less likely to divest unique subsidiaries since they may function as platforms to expand their operations in case new opportunities arise in the host country (e.g. Belderbos and Zou, 2009; Berry 2013).

We include several control variables at the parent firm level. Firm size is measured as the logarithm of the firm's consolidated assets. Larger firms may possess greater financial resources to execute divestment decisions (Li, 1995; Pennings and Sleuwaegen, 2000; Getachew and Beamish, 2017). We also include the variable resource intensity (Belderbos and Sleuwaegen, 2005; Caves, 2007; Chang, 1995), calculated as the ratio of general and administrative expenses (including marketing and R\&D expenditures) over sales. Resourceful firms may be more competitive in foreign markets. We also control for parent firm performance, as poorly performing firms are likely to be under more pressure to divest foreign subsidiaries in corporate restructuring: Return on assets (ROA) is calculated as the ratio of net income to total assets. Previous firm experience in international operations can influence divestment decisions as well (Belderbos and Zou, 2009; Benito, 1997; Iurkov and Benito, 2018). International experience is the number of years the firm has been operating in international markets and is calculated as the difference between the focal year and the year in which the firm established its first foreign subsidiary. We include the number of manufacturing industries in which the firm is active as a measure of parent firm diversification. Finally, we control for potential co-location advantages with other value-chain activities of the firm by adding three dummy variables: sales co-location (a dummy that takes the value 1 if the firm owns a sales office in the focal country and industry), $R \& D$ co-location (a dummy that takes the value 1 if the firm has an R\&D center in the focal country), $H Q$ co-location (a dummy that takes the value 1 if the firm has a regional headquarter in the focal country).

MNCs' international operations are also affected by the economic health of the global industry. We include the variable industry contraction, constructed as a dummy variable taking the value 1 if the three-year moving average growth rate of industry world production is negative. Subsidiaries in declining industries could face higher divestment pressure if firms adjust their operations when confronted with adverse industry conditions.

\section{Methods}

For hypothesis 1 , we conduct a multivariate analysis relating the degree of efficiency orientation of the MNC to global industry integration and a set of firm characteristics and time dummies. Since the dependent variable is a share and hence restricted to the interval $[0,1]$ we estimate a Tobit model with two-way censoring.

For hypotheses 2 and 3, our dependent variable subsidiary divestment is a non-repeatable event that can only be observed during the period of analysis (1990-2004). This leads to right-censoring in the data that can be dealt with survival analysis techniques. We follow prior studies and take the semiparametric Cox proportional hazard model for our estimation, as it does not require specifying the baseline hazard function (Cleves et al., 2016). ${ }^{3}$ Analysis time or the period at risk starts at the first year that we observe the subsidiary. In cases where the subsidiary started as a sales unit but only later expanded to include manufacturing activities, it is the starting year of manufacturing activities, consistent with our theory on manufacturing divestments. We note that the models control for age and age square to bring in the experience of the subsidiaries.

Hypotheses 2 and 3 are tested by performing split sample analyses. We divide the full sample into two sets of observations: one group of subsidiaries active in integrated industries (global industry integration above the median) and another group of subsidiaries active in fragmented industries with global industry integration below the median(for convenience labelled nonintegrated industries). Hypotheses 2 and 3

\footnotetext{
${ }^{3}$ We observe near-identical results when we employ discrete-time survival models instead (Jenkins, 1995: the generalized linear model with a link complementary log-log function (cloglog). Results available from the authors upon request. We note that in the context of the Cox model with the time scale of the hazard specified as 'time-on', subsidiary age can be included as an additional covariate, since the Cox model requires no specific assumptions about the shape of the hazard over time (Cleves et al., 2016, p 2-5, p 21-27, p 131-133).
} 
predict a strong positive coefficient on host country labor costs in the subsample of integrated industries and a strong negative coefficient on host country demand growth in the subsample of nonintegrated industries.

We follow this approach rather than using interaction terms because this allows coefficients of all covariates to differ between the two groups, guaranteeing consistent within-group estimates (Hoetker, 2007). This is important as other influences on divestments than labor cost and demand conditions also vary across industry environments. If they do, then an approach with interaction effects, only allowing the focal variable coefficient to vary in global industry integration, delivers biased estimates. Statistical tests (loglikelihood ratio tests) clearly rejected the hypothesis that the other coefficients could be set to be equal in high versus low integrated industries, suggesting the use of split sample analysis. A drawback of this required approach is that we only evaluate the role of global industry integration above and below the median and not for the entire distribution of global integration levels. We therefore also examine the results of models applying different cutoff values in the distribution of global industry integration, in order to examine whether there is consistency in the patterns we observe. We report on this in the supplementary analysis section.

To test Hypotheses 4 and 5, the sample of integrated industries and the sample of fragmented industries are further divided into subsamples of firms with a strong revealed efficiency orientation and subsamples of firms with less efficiency oriented firms. Hence, we distinguish four subsamples, i.e., high integration and high efficiency $(\mathrm{HH})$, high integration and low efficiency (HL), low integration and high efficiency (LH) and low integration and low efficiency (LL). Hypotheses 4 and 5 predict that in the $\mathrm{HH}$ sample the effect of labor cost is the most salient while for $\mathrm{LL}$, the effect of demand is most important. Also here, statistical tests suggest that coefficients are not equal across subsamples, mandating split sample analysis.

All variables across models are lagged by one year to allow for managerial response time and a proper time ordering. Year and industry dummies are included to control for macroeconomic shocks and industry specific effects. Standard errors are clustered at the firm level (efficiency orientation model) or at the subsidiary level (divestment hazard model).

\section{Empirical results}

Tables 3 and 4 report descriptive statistics and pairwise correlations for the divestment model. ${ }^{4}$. In Table 4, the correlation levels among the independent variables in absolute terms are all below 0.6 and multicollinearity does not appear to be a major concern.

Results of the Tobit model relating MNC efficiency orientation to global industry integration and a set of firm characteristics and time dummies are reported in Table 5 . We observe a positive and highly significant coefficient of global industry integration, in support of Hypothesis 1 stating that MNCs are inclined to align their strategy with the global industry environment. The magnitude of the coefficient suggests that, taking the degree of left censoring into account, a standard deviation change in global industry integration increases the efficiency orientation of MNCs by 4.8 percent points. Among the control variables, firm size (negative), ROA (negative) and firm experience (positive) are significant. These negative signs for size and ROA may indicate that for larger firms it may be more difficult and costly to be responsive to changes in the industry environment, while profitable firms may find adjustment less necessary and may have adopted a market oriented strategy based on unique capabilities (e.g. Collis, 1991; Leonard Barton, 1992). The positive sign for experience may signal that young MNCs are more likely to be niche players focusing on product and service

\footnotetext{
${ }^{4}$ The statistics for the efficiency orientation model testing $\mathrm{H} 1$ are available upon request.
}

development rather than on cost competition (e.g. Oviatt and McDougal, 1994).

Results from the Cox models examining the differential effects of labor cost and demand growth on the probability of subsidiary divestment across the two industry environments are presented in Table 6. Model 6.1 shows the results for the full sample; Models 6.2 and 6.3 show the results for subsidiaries in integrated versus nonintegrated (fragmented) industries. A log-likelihood ratio test (Allison, 1999) rejects that the model coefficients are equal in support of the split sample estimation (Chi-square (40) $=13155.7, \mathrm{p}<0.000$.). In the full sample Model 6.1, labor cost and demand growth are important significant factors in divestment decisions. As expected, the coefficient of labor cost is positive and significant while the coefficient of demand growth is negative and significant. The coefficient estimates imply that a one standard deviation increase in labor cost (demand growth) leads to a 29 (22) \% proportional increase (decrease) in the hazard of divestment. ${ }^{5}$

A more nuanced picture emerges once we distinguish between industries with high versus low levels of global integration. In model 6.2 (integrated industries) the coefficient on labor cost is significant and particularly large $(0.350)$, implying a $36 \%$ proportional increase in the hazard of divestment due to a standard deviation increase in labor cost. In Model 6.3 (nonintegrated industries), the coefficient reduces to 0.212. Conversely, the coefficient of demand growth in Model 6.3 (nonintegrated industries) is highly significant and substantially larger than the counterpart in Model 6.2 (integrated industries), where the coefficient is only marginally significant. The proportional decrease in the hazard of divestment due to one standard deviation increase in demand growth is 24 percent in nonintegrated industries. These findings provide strong support for Hypotheses 2 and 3. Chow tests moreover suggest that the coefficients of labor cost and demand growth are strongly and marginally significantly different between the high and low global industry integration subsamples, respectively (Chi-square (1)= 8.91, $\mathrm{p}=0.0028$ and Chi-square $(1)=2.94, \mathrm{p}=0.0866$, respectively).

Table 7 reports the results for the 4 subsamples to examine the support for Hypotheses 4 and 5. In line with Hypotheses 4 and 5, MNCs are more inclined to react to high labor cost by divesting subsidiaries in highly integrated industries in particular when firms have adopted an outspoken efficiency orientation strategy: across the 4 subsamples, the coefficient of labor cost is the most significant and of the highest magnitude in model 7.1. Demand growth is of less consideration in these conditions, as manifested by the insignificance of the coefficient. In contrast, in the subsample of low integration and in the absence of a pronounced efficiency orientation, MNCs are very responsive to demand condition. As seen in model 7.4, demand growth is highly significant and its coefficient has the largest magnitude among the subsamples, while labor cost is not significant. In the other two subsamples, the coefficients and significance of the labor cost and demand growth coefficients are somewhere in between these two cases, as one would expect. Chow tests show that the differences between coefficients of labor cost and demand growth between model 7.1 and model 7.4 are significant (Chi-square (1) $=7.31, \mathrm{P}=0.0069$ and Chi-square $(1)=4.36, \mathrm{p}=0.0368$, respectively). The results suggest broad support for Hypotheses 4 and 5: the most pronounced effect of labor cost on divestment is found for MNCs that have aligned their strategy with the situation of global industry integration, and the most pronounced effect of demand growth is observed for MNCs that have a strategy that is aligned with a situation of global industry fragmentation.

Several control variables appear to affect subsidiary divestment decision in Table 6. Small operations are more likely to be divested, as are joint ventures (Li, 1995; Mata and Portugal, 2000; Berry, 2013; Makino

\footnotetext{
5 The coefficients in exponentiated form reflect the proportional increase in the hazard of divestment following a unit change in the independent variable. From the labor cost coefficient estimate of 0.290 in Model 6.1 and a standard deviation of labor cost of 0.872 , we get $e^{(0.290 * 0.872)}-1=0.29$.
} 
Table 4

Correlations

\begin{tabular}{|c|c|c|c|c|c|c|c|c|c|c|c|c|c|c|c|c|c|c|c|c|c|c|c|c|}
\hline & Variable & 1 & 2 & 3 & 4 & 5 & 6 & 7 & 8 & 9 & 10 & 11 & 12 & 13 & 14 & 15 & 16 & 17 & 18 & 19 & 20 & 21 & 22 & 23 \\
\hline 1 & Divestment & 1.00 & & & & & & & & & & & & & & & & & & & & & & \\
\hline 2 & $\begin{array}{l}\text { Global industry } \\
\text { integration }\end{array}$ & 0.01 & 1.00 & & & & & & & & & & & & & & & & & & & & & \\
\hline 3 & $\begin{array}{l}\text { Firm efficiency } \\
\text { orientation }\end{array}$ & 0.01 & 0.17 & 1.00 & & & & & & & & & & & & & & & & & & & & \\
\hline 4 & Labor cost & 0.06 & -0.05 & -0.11 & 1.00 & & & & & & & & & & & & & & & & & & & \\
\hline 5 & Demand growth & -0.05 & -0.02 & 0.10 & -0.41 & 1.00 & & & & & & & & & & & & & & & & & & \\
\hline 6 & $\begin{array}{l}\text { Japanese } \\
\text { agglomeration }\end{array}$ & -0.01 & 0.36 & 0.03 & -0.12 & 0.23 & 1.00 & & & & & & & & & & & & & & & & & \\
\hline 7 & RCA & 0.01 & 0.15 & 0.16 & 0.09 & 0.03 & 0.19 & 1.00 & & & & & & & & & & & & & & & & \\
\hline 8 & Market Uncertainty & -0.01 & 0.09 & 0.03 & -0.25 & -0.40 & -0.13 & -0.05 & 1.00 & & & & & & & & & & & & & & & \\
\hline 9 & Political risk & 0.03 & -0.07 & -0.06 & 0.31 & -0.55 & -0.32 & -0.02 & 0.17 & 1.00 & & & & & & & & & & & & & & \\
\hline 10 & $\begin{array}{l}\text { Transport } \\
\text { infrastructure }\end{array}$ & -0.01 & 0.04 & 0.02 & -0.14 & -0.13 & -0.05 & -0.05 & 0.57 & -0.05 & 1.00 & & & & & & & & & & & & & \\
\hline 11 & Trade openness & -0.02 & -0.02 & 0.10 & 0.00 & 0.08 & -0.11 & 0.07 & 0.06 & -0.04 & -0.07 & 1.00 & & & & & & & & & & & & \\
\hline 12 & Age subsidiary & 0.00 & 0.04 & 0.04 & 0.14 & -0.19 & -0.17 & 0.02 & 0.09 & 0.24 & 0.04 & 0.24 & 1.00 & & & & & & & & & & & \\
\hline 13 & Minority owned & 0.03 & -0.08 & -0.07 & -0.19 & 0.07 & -0.05 & -0.13 & 0.06 & 0.03 & 0.06 & -0.03 & 0.01 & 1.00 & & & & & & & & & & \\
\hline 14 & Subsidiary size & -0.05 & 0.09 & 0.13 & -0.13 & 0.02 & 0.12 & 0.16 & 0.04 & 0.01 & 0.04 & -0.04 & 0.27 & 0.04 & 1.00 & & & & & & & & & \\
\hline 15 & Unique subsidiary & -0.02 & -0.06 & -0.02 & 0.11 & -0.14 & -0.32 & -0.06 & 0.07 & 0.17 & 0.04 & 0.12 & 0.06 & -0.05 & -0.18 & 1.00 & & & & & & & & \\
\hline 16 & Sales co-location & 0.03 & 0.12 & 0.02 & 0.20 & -0.05 & 0.23 & 0.14 & -0.13 & -0.05 & -0.10 & -0.05 & -0.01 & -0.05 & 0.16 & -0.24 & 1.00 & & & & & & & \\
\hline 17 & R\&D co-location & 0.01 & 0.09 & -0.01 & 0.10 & 0.01 & 0.19 & 0.07 & -0.09 & -0.06 & -0.05 & -0.04 & -0.01 & 0.01 & 0.14 & -0.17 & 0.28 & 1.00 & & & & & & \\
\hline 18 & HQ co-location & 0.02 & 0.08 & -0.03 & 0.12 & 0.01 & 0.22 & 0.06 & -0.12 & -0.10 & -0.06 & -0.10 & -0.05 & 0.01 & 0.10 & -0.22 & 0.27 & 0.39 & 1.00 & & & & & \\
\hline 19 & Firm experience & 0.00 & 0.20 & -0.01 & -0.02 & -0.07 & 0.05 & 0.04 & 0.07 & 0.01 & 0.04 & -0.04 & 0.28 & 0.02 & 0.26 & -0.23 & 0.26 & 0.16 & 0.15 & 1.00 & & & & \\
\hline 20 & Firm diversification & 0.01 & 0.13 & 0.01 & -0.01 & -0.03 & -0.02 & 0.00 & 0.03 & 0.00 & 0.03 & -0.03 & 0.02 & 0.04 & 0.14 & -0.21 & 0.29 & 0.18 & 0.17 & 0.37 & 1.00 & & & \\
\hline 21 & ROA & -0.03 & -0.09 & -0.07 & 0.04 & 0.02 & -0.01 & -0.06 & -0.05 & 0.03 & -0.02 & 0.01 & 0.03 & -0.04 & -0.02 & 0.05 & -0.06 & -0.06 & -0.06 & -0.01 & -0.10 & 1.00 & & \\
\hline 22 & $\begin{array}{l}\text { Firm resource } \\
\text { intensity }\end{array}$ & 0.02 & -0.04 & -0.03 & -0.01 & 0.04 & -0.03 & 0.03 & -0.01 & -0.07 & -0.01 & 0.02 & 0.08 & -0.06 & -0.05 & 0.00 & 0.12 & 0.08 & 0.05 & 0.16 & -0.05 & 0.01 & 1.00 & \\
\hline 23 & Firm size & 0.01 & 0.03 & -0.07 & -0.02 & -0.02 & -0.01 & 0.01 & 0.00 & 0.00 & -0.01 & -0.07 & 0.07 & 0.04 & 0.35 & -0.32 & 0.41 & 0.29 & 0.28 & 0.58 & 0.55 & -0.04 & 0.12 & 1.00 \\
\hline 24 & Industry contraction & 0.00 & 0.14 & 0.04 & 0.00 & -0.03 & -0.03 & 0.04 & 0.05 & 0.00 & 0.06 & 0.00 & 0.04 & -0.02 & 0.00 & 0.00 & 0.01 & -0.01 & 0.00 & 0.04 & 0.02 & -0.17 & -0.02 & -0.01 \\
\hline
\end{tabular}


Table 5

MNC efficiency orientation and global industry integration (H1).

\begin{tabular}{ll}
\hline & Model \\
\hline Global industry integration & $0.382^{* * *}$ \\
Firm experience & $(0.077)$ \\
& $0.002^{* *}$ \\
Firm diversification & $(0.001)$ \\
& -0.006 \\
ROA & $(0.009)$ \\
Firm resource intensity & $-0.411^{*}$ \\
& $(0.230)$ \\
Firm size & -0.053 \\
Industry contraction & $(0.099)$ \\
& $-0.017^{* *}$ \\
Constant & $(0.007)$ \\
& 0.006 \\
Year dummies & $(0.009)$ \\
Observations & $0.356^{* * *}$ \\
F statistic & $(0.132)$ \\
Log likelihood & YES \\
Pseudo-R-squared & 7,325 \\
\hline
\end{tabular}

Notes: Results of a Tobit model. The dependent variable is the share of efficiency oriented

manufacturing subsidiaries of the MNC. Clustered standard errors in parentheses $* * * \mathrm{p}<0.01$,

$* * \mathrm{p}<0.05, * \mathrm{p}<0.01$

and Beamish, 1998; Dhanaraj and Beamish, 2004; Fang et al., 2007). Similarly to previous studies(Li, 1995; Belderbos and Zou, 2009; Dhanaraj and Beamish, 2004; Mata and Portugal, 2000), we find in all models that subsidiaries are generally less likely to survive as they get older, which may be related to organizational inertia (Hannan, 1998) or increasing competitive pressure over time. The effect of age on divestment decreases with time and eventually turns negative at 19 years in the full sample model, perhaps because subsidiaries that have survived for a long time have proven to be well positioned in their host country. Parent firm performance and a subsidiary's role as a country platform (unique subsidiary) reduce the hazard of divestment both in fragmented and integrated industries (e.g. Belderbos and Zou, 2009).

Differential effects of divestment drivers are observed depending on global industry integration. The coefficient of market uncertainty is negative and significant only in integrated industries. This finding is somewhat surprising, as one may expect that host country-specific sunk costs and investment hysteresis are higher in fragmented industries where host country market characteristics are important (Kogut and Kulatilaka, 1994; Chung et al., 2013). A possible explanation is that uncertainty in general is also associated with investment hysteresis and the value of waiting to divest in efficiency oriented networks aiming for global efficiency may be higher (Belderbos and Zou, 2009). Japanese agglomeration economies reduce the divestment hazard of foreign subsidiaries in integrated industries. By collocating manufacturing activities with other Japanese firms, multinational firms can generate external economies of scale and cost reduction via common pools of suppliers and labor (Belderbos and Carree, 2002; Chung and Song, 2004; Head, Ries and Swenson, 1995). Firm diversification is also a factor that is more relevant for subsidiaries in integrated industries. Perhaps such subsidiaries take on a more flexible role in MNCs' integrated manufacturing network and can accommodate shifts in product mix and specialization. Finally, we observe that industry contraction is a significant driver in integrated industries, which is consistent with the notion of stronger pressure on efficiency due to increased competition.

\section{Supplementary analysis}

We conducted a number of supplementary analyses to examine the
Table 6

Cox proportional hazard model analysis of the drivers of subsidiary divestment: integrated vs. nonintegrated (fragmented) industries (H2-H3).

\begin{tabular}{|c|c|c|c|}
\hline & $\begin{array}{l}\text { Full } \\
\text { sample } \\
\text { Model } 6.1\end{array}$ & $\begin{array}{l}\text { Integrated } \\
\text { Industries } \\
\text { Model } 6.2\end{array}$ & $\begin{array}{l}\text { Non-integrated } \\
\text { Industries } \\
\text { Model } 6.3\end{array}$ \\
\hline Labor cost & $\begin{array}{l}0.290 * * * \\
(0.061)\end{array}$ & $\begin{array}{l}0.350 * * * \\
(0.080)\end{array}$ & $\begin{array}{l}0.212^{* *} \\
(0.094)\end{array}$ \\
\hline Demand growth & $\begin{array}{l}-0.076^{* * * *} \\
(0.021)\end{array}$ & $\begin{array}{l}-0.061 * \\
(0.032)\end{array}$ & $\begin{array}{l}-0.086^{* * *} \\
(0.029)\end{array}$ \\
\hline $\begin{array}{l}\text { Japanese } \\
\text { agglomeration }\end{array}$ & $\begin{array}{l}-0.129 * * * \\
(0.046)\end{array}$ & $\begin{array}{l}-0.145^{* *} \\
(0.066)\end{array}$ & $\begin{array}{l}-0.096 \\
(0.068)\end{array}$ \\
\hline RCA & $\begin{array}{l}0.203 \\
(0.133)\end{array}$ & $\begin{array}{l}0.268 \\
(0.220)\end{array}$ & $\begin{array}{l}0.274 \\
(0.173)\end{array}$ \\
\hline Market Uncertainty & $\begin{array}{l}-1.968^{* *} \\
(0.884)\end{array}$ & $\begin{array}{l}-3.643^{* * *} \\
(1.225)\end{array}$ & $\begin{array}{l}-0.702 \\
(1.418)\end{array}$ \\
\hline Political risk & $\begin{array}{l}0.211 \\
(0.261)\end{array}$ & $\begin{array}{l}0.417 \\
(0.375)\end{array}$ & $\begin{array}{l}0.145 \\
(0.389)\end{array}$ \\
\hline $\begin{array}{l}\text { Transport } \\
\text { infrastructure }\end{array}$ & $\begin{array}{l}0.885 \\
(13.917)\end{array}$ & $\begin{array}{l}-4.931 \\
(17.586)\end{array}$ & $\begin{array}{l}26.110 \\
(33.991)\end{array}$ \\
\hline Trade openness & $\begin{array}{l}-0.084 * \\
(0.051)\end{array}$ & $\begin{array}{l}-0.069 \\
(0.067)\end{array}$ & $\begin{array}{l}-0.084 \\
(0.081)\end{array}$ \\
\hline Age subsidiary & $\begin{array}{l}0.082 * * * \\
(0.021)\end{array}$ & $\begin{array}{l}0.064^{*} \\
(0.035)\end{array}$ & $\begin{array}{l}0.086^{* * *} \\
(0.027)\end{array}$ \\
\hline $\begin{array}{l}\text { Age subsidiary } \\
\text { squared }\end{array}$ & $(0.001)$ & $(0.001)$ & $\begin{array}{l}-0.002^{* *} \\
(0.001)\end{array}$ \\
\hline Minority owned & $\begin{array}{l}0.567 * * * \\
(0.083)\end{array}$ & $\begin{array}{l}0.556 * * * \\
(0.114)\end{array}$ & $\begin{array}{l}0.582 * * * \\
(0.124)\end{array}$ \\
\hline Subsidiary size & $\begin{array}{l}-0.272 * * * \\
(0.032)\end{array}$ & $\begin{array}{l}-0.283^{* * *} \\
(0.045)\end{array}$ & $\begin{array}{l}-0.257^{* * * *} \\
(0.046)\end{array}$ \\
\hline Unique subsidiary & $\begin{array}{l}-0.429 * * * \\
(0.095)\end{array}$ & $\begin{array}{l}-0.378^{* * *} \\
(0.135)\end{array}$ & $\begin{array}{l}-0.514^{* * * *} \\
(0.134)\end{array}$ \\
\hline Sales co-location & $\begin{array}{l}0.109 \\
(0.107)\end{array}$ & $\begin{array}{l}0.089 \\
(0.143)\end{array}$ & $\begin{array}{l}0.146 \\
(0.164)\end{array}$ \\
\hline $\mathrm{R} \& \mathrm{D}$ co-location & $\begin{array}{l}-0.130 \\
(0.191)\end{array}$ & $\begin{array}{l}0.005 \\
(0.226)\end{array}$ & $\begin{array}{l}-1.114^{* *} \\
(0.521)\end{array}$ \\
\hline HQ co-location & $\begin{array}{l}-0.004 \\
(0.163)\end{array}$ & $\begin{array}{l}-0.074 \\
(0.213)\end{array}$ & $\begin{array}{l}0.036 \\
(0.270)\end{array}$ \\
\hline Firm experience & $\begin{array}{l}-0.005 \\
(0.005)\end{array}$ & $\begin{array}{l}-0.003 \\
(0.007)\end{array}$ & $\begin{array}{l}-0.009 \\
(0.007)\end{array}$ \\
\hline Firm diversification & $\begin{array}{l}-0.036 \\
(0.032)\end{array}$ & $\begin{array}{l}-0.088^{* *} \\
(0.043)\end{array}$ & $\begin{array}{l}0.020 \\
(0.049)\end{array}$ \\
\hline ROA & $\begin{array}{l}-5.497 * * * \\
(1.440)\end{array}$ & $\begin{array}{l}-4.691 * * * \\
(1.719)\end{array}$ & $\begin{array}{l}-6.655^{* * *} \\
(2.573)\end{array}$ \\
\hline $\begin{array}{l}\text { Firm resource } \\
\text { intensity }\end{array}$ & $\begin{array}{l}0.905 \\
(0.584)\end{array}$ & $\begin{array}{l}0.376 \\
(0.790)\end{array}$ & $\begin{array}{l}1.680 * * \\
(0.857)\end{array}$ \\
\hline Firm size & $\begin{array}{l}0.079 * \\
(0.041)\end{array}$ & $\begin{array}{l}0.148 * * \\
(0.059)\end{array}$ & $\begin{array}{l}0.019 \\
(0.059)\end{array}$ \\
\hline Industry contraction & $\begin{array}{l}0.078 \\
(0.119)\end{array}$ & $\begin{array}{l}0.387 * * \\
(0.181)\end{array}$ & $\begin{array}{l}0.060 \\
(0.191)\end{array}$ \\
\hline Observations & 29,205 & 14,452 & 14,753 \\
\hline Industry FE & YES & YES & YES \\
\hline Year FE & YES & YES & YES \\
\hline $\begin{array}{l}\text { Number of } \\
\text { divestments }\end{array}$ & 654 & 354 & 300 \\
\hline Model chi-square & 474.3 & 4069 & 209.8 \\
\hline Log likelihood & -4792 & -2310 & -2046 \\
\hline
\end{tabular}

Notes: clustered standard errors in parentheses $* * * \mathrm{p}<0.01,{ }^{* *} \mathrm{p}<0.05,{ }^{*} \mathrm{p}<0.1$. The LR test (Model 1 vs Models 2, 3) is $871.23^{* * *}$.

The Chow tests of coefficient equality are $8.91 * * *$ and $2.94 *$ for labor cost and demand growth respectively (Model 2 vs Model 3).

robustness and consistency of our findings. We reran the model using the discrete survival analysis, i.e., complementary log-log regression, and obtained similar results (Jenkins, 1995; Cleves et al., 2016). We also examined the robustness of our findings under different definitions of the sample. Our findings did not change if we limited the analysis to subsidiaries with at least 20 employees to ensure that the sample does not include potential wrongly assigned sales subsidiaries or distribution offices (Beamish and Inkpen, 1998), or if we limited observations to subsidiaries in which the parent firm had at least a $25 \%$ equity stake. To 
Table 7

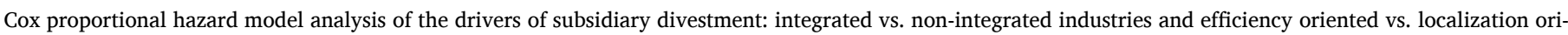
ented MNC strategies.

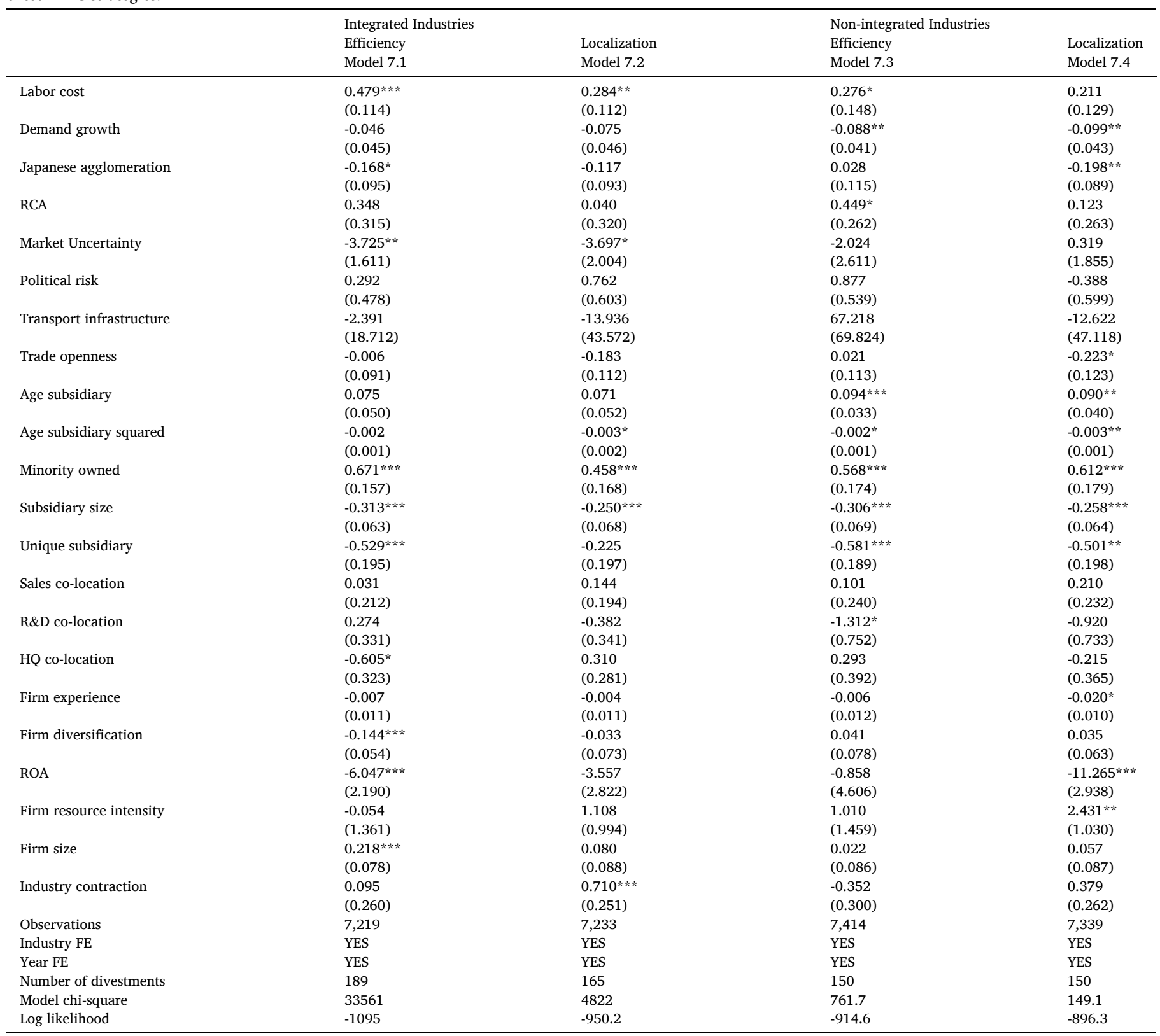

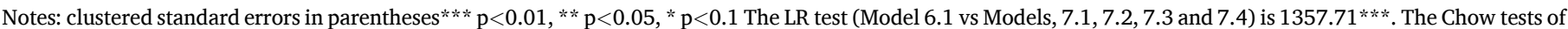
coefficient equality are $7.31^{* * *}$ and $4.36^{* *}$ for labor cost and demand growth respectively (Model 7.1 vs Model 7.4).

examine if the absence of an explicit sunk cost measure in our models (due to the unavailability of data on subsidiaries' capital intensity) may affect our findings, we estimated a model including a proxy for capital intensity at the industry-country level and a model with the observations in the top decile of this capital intensity distribution excluded - with similar results. As a further robustness analysis, we estimated models with additionally country dummies included and found similar results. Since the country dummies correlate with the country variables, while the country variables provide more insights into the systematic relationships between country characteristics and the likelihood of divestment, we prefer the models without country dummies.

Finally, we examined the pattern of coefficient estimates for different levels of the cutoff point of global industry integration. In addition to examining coefficients at the median, we report coefficients when the cutoff point is at a higher level of global integration (the $66^{\text {th }}$ and $75^{\text {th }}$ percentile) and a lower cutoff point (the $33^{\text {th }}$ and $25^{\text {th }}$ percentile). We find that the pattern of differences is consistent for all cutoff points: labor cost coefficients are higher for integrated industries at the highest levels and demand growth coefficients are more strongly negative for non-integrated industries at the lowest levels. At the highest cutoff point, demand growth is no longer significant in integrated industries while at the lower cutoff points, labor cost is no longer significant in non-integrated industries. These patterns attest to the consistency and robustness of our findings. 


\section{Discussion}

This paper investigates how global market integration forces affect the divestment drivers of foreign subsidiaries. In a sample of 650 Japanese firms operating 3827 foreign Japanese manufacturing subsidiaries observed during the years 1990-2004, we find that competitive forces in globally integrated industries are associated with a more pronounced efficiency orientation in MNCs' subsidiary networks. In integrated industries, the hazard of affiliate divestment is strongly increased in host countries with local labor costs. In contrast, in non-integrated (fragmented) industries, MNCs are more likely to adopt a local market orientation strategy in their affiliate network, and it is the absence of local market growth that is the more important driver of divestment. The strongest influence of labor cost on divestment is observed for subsidiaries of MNCs with an (aligned) pronounced efficiency oriented strategy operating in integrated industries, while the strongest influence of (the absence of) local demand growth on divestment is observed for subsidiaries of MNCs with an (aligned) localization strategy operating in fragmented industries.

Our study contributes to the literature on subsidiary divestments by specifically taking into account the global industry context and related strategic MNC motivations. We show how industry conditions shape the strategic orientation and global subsidiary networks of MNCs and the role of host country drivers in divestment decisions. The impact of known host country drivers of divestments exhibits important heterogeneity depending on the nature of the global industry environment - a notion that has not received attention in prior literature. By introducing the global industry context and associated MNC strategy, our study qualifies and extends extant research that paid limited attention to subsidiary characteristics, host country factors or parent firm traits (e.g. Berry, 2013; Mata and Portugal, 2000; Benito, 1997; Li, 1995; Fang et al. 2013; Getachew and Beamish, 2017; Song, 2015; Dai, Eden and Beamish, 2017; Tan and Sousa, 2018). Hence, we answer to the call to give proper attention to MNCs' strategic considerations behind divestment decisions (Schmid and Morschett, 2020).

Our findings are consistent with the general notion in the theoretical framework of Benito (2005) that subsidiary investment decisions should be seen in the context of MNC strategies responding to changing global business conditions. We expand and refine this idea by showing that adjustments in subsidiary networks under competitive pressures depend crucially on host country conditions. It is not necessarily global industry integration itself (Berry, 2013; Iurkov and Benito, 2018) but the interaction between global industry conditions and host country market and cost characteristics that influences divestment decisions - in a heterogeneous manner across countries. In this regard, our study also adds to recent empirical work investigating heterogeneity in the drivers of subsidiary divestments in different host country environments (Makino et al., 2007; Getachew and Beamish, 2017; Tan and Sousa, 2018; Berry, 2013).

Our findings suggest that MNCs will need to closely monitor the changing global industry context in connection to developments in locational (dis)advantages across (potential) subsidiary locations. Implicit in our analysis is the suggestion that MNCs that adapt strategies to the changing global industry context are better able to sustain their competitive advantage, where necessary through targeted divestment and relocation of activities. In this regard, our results are consistent with the notion in the responsiveness versus integration framework (e.g. Prahalad \& Doz, 1987) that the balance between local demand oriented and global integration oriented strategies depends on the (changing) state of the global and local environment. Yet the heterogeneity in the degree to which MNCs' international strategy is adapted and aligned with global industry development may also differ in accordance with specific opportunities in industry niches and MNCs' value creation capabilities based on their firm specific resources and capabilities. Clearly, exploring the potential performance implications of divestment behaviour in the context of global industry integration and the presence or absence of aligned international strategies will be a valuable avenue for further research.

Our study also contributes to existing research on global competition and associated firm responses (Kobrin, 1991; Wiersema and Bowen, 2008; Morrison and Roth, 1992; Chang and Rhee, 2011;) by taking into account how global industry forces shape the fate of individual subsidiaries in their local environment. Extant research has primarily examined the impact of global competition at the parent firm level, investigating firm traits (Kobrin, 1991), strategies (Morrison and Roth, 1992) and (the performance of) international expansion (Chang and Rhee, 2011; Wiersema and Bowen, 2008) of firms active in global industries, but without specifying consequences for their international production network or subsidiaries. Our study contributes to this literature by providing arguments and empirical support for the notion that MNCs' strategic adjustments to the global industry environment crucially affect the evolution of foreign subsidiaries and the impact of (host country) drivers of subsidiary divestment.

The current study is not without limitations. We adopted a revealed measure of MNCs' efficiency orientation derived from investment purposes reported for the MNCs' foreign manufacturing subsidiaries. While this delivered intuitive results, the underlying investment purpose data we could draw on are far from perfect. Future research may seek to complement the analysis with a specific survey at the parent firm level concerning their strategic goals and posture. Second, we were not able to use a more disaggregated classification of subsidiaries' industries. Broadly defined industries may encompass a wider array of diverse products that may be subject to different integration pressures and that may require different strategic responses. Third, we could not distinguish between plant closures and equity sell-offs to a third party. This may put a downward bias on our results as equity sell-offs may be less driven by changes in the local environment. Fourth, our analysis focused on global industry drivers in combination with host country factors, but could not take into account subnational heterogeneity in environmental circumstances related to local agglomeration factors and cost developments. Fifth, we could not distinguish between types of labor to identify potential mechanisms of skill upgrading of subsidiaries in high wage countries subject to integration forces (Mion and Zhu, 2013). This could downward bias our results as MNCs in integrated industries may downsize their subsidiaries and keep high skilled workers instead of divesting subsidiaries. Finally, our study is confined to the divestment behaviour of Japanese firms during the period 1990-2014. It would be interesting to investigate if our findings carry over to divestment decisions by MNCs originating from other countries. Although the period of investigation is a good match with our research questions as it covers the years of strongly increasing global industry integration, it would clearly be of interest to examine these relationships in more recent years characterized by a return to trade friction and protectionism. We hope that future research can seek to address these limitations.

\section{Conclusion}

The purpose of this paper is to study how global market integration forces affect the divestment drivers of foreign subsidiaries. In globally integrated industries, where barriers to trade are low and import penetration is high, MNCs face strong competitive pressure for efficiency, tend to adopt efficiency oriented network strategies and seek to serve global markets by choosing the best locations to reduce costs and realize global economies of scale. Hence, high wage costs in host countries strongly increase the hazard of subsidiary divestment in globally integrated industries. In contrast, in non-integrated (fragmented) industries, MNCs adopt local market oriented strategies, and host country demand growth is a more important driver of subsidiary survival. If this paper could have one message, it is the necessity to explicitly consider the global industry context to properly understand the affiliate divestment decisions of multinational firms. This implies the need of taking into account global market integration forces and MNCs' 
broader affiliate network strategies. Including this perspective will be helpful to researchers, managers, policy makers, and all those concerned with divestment behavior of MNCs abroad.

\section{Acknowledgements}

René Belderbos and Leo Sleuwaegen acknowledge financial support from FWO-Science Foundation Flanders under grant number G049711N10. Shubin Wu acknowledges support from National Natural Science Foundation of China (Grant Number: NSFC-71672105, NSFC71972121), as well as support from Program for Innovative Research Team of Shanghai University of Finance and Economics.

\section{References}

Allison, P. D. (1999). Comparing logit and probit coefficients across groups. Sociological Methods and Research, 28(2), 186-208.

Ahlstrom, D., Bruton, G. D., \& Zhao, L. (2013). Turning good research into good publications. Nankai Business Review International, 4(2), 92-106.

Arribas, I., Pérez, F., \& Tortosa-Ausina, E. (2009). Measuring globalization of international trade: theory and evidence. World Development, 37(1), 127-145.

Babones, S. (2008). Studying Globalization: Methodological Issues. Blackwell Publishing Ltd.

Bartlett, C. A., \& Ghoshal, S. (1989). Managing across borders: The transnational solution. Harvard Business Press.

Beamish, P. W., \& Inkpen, A. C. (1998). Japanese firms and the decline of the Japanese expatriate. Journal of World Business, 33(1), 35-50.

Belderbos, R., \& Carree, M. (2002). The location of Japanese investments in China: Agglomeration effects, keiretsu, and firm heterogeneity. Journal of the Japanese and International Economies, 16(2), 194-211.

Belderbos, R., Du, H., \& Slangen, A. (2020). When Do Firms Choose Global Cities as Foreign Investment Locations? The Roles of Contextual Distance and Value-Chain Activities' Knowledge Intensity. Journal of World Business, 55(1), 2-13.

Belderbos, R., \& Grimpe, C. (2020). Learning in foreign and domestic value chains: The role of opportunities and capabilities. Industrial and Corporate Change, 30, 1-20. https://doi.org/10.1093/icc/dtaa027.

Belderbos, R., \& Sleuwaegen, L. (2005). Competitive drivers and international plant configuration strategies: A product-level test. Strategic Management Journal, 26(6), 577-593.

Belderbos, R., \& Sleuwaegen, L. (1998). Tariff jumping DFI and export substitution: Japanese electronics firms in Europe. International Journal of Industrial Organization, 16(5), 601-638.

Belderbos, R., Tong, T. W., \& Wu, S. (2014). Multinationality and downside risk: The roles of option portfolio and organization. Strategic Management Journal, 35(1), 88-106.

Belderbos, R., \& Zou, J. (2009). Real options and foreign affiliate divestments: A portfolio perspective. Journal of International Business Studies, 40(4), 600-620.

Belderbos, R., \& Zou, J. (2007). On the growth of foreign affiliates: Multinational plant networks, joint ventures, and flexibility. Journal of International Business Studies, 38 (7), 1095-1112.

Belk, R. W. (1996). Hyperreality and globalization: Culture in the age of Ronald McDonald. Journal of International Consumer Marketing, 8(3-4), 23-37.

Benito, G. R. (1997). Divestment of foreign production operations. Applied Economics, 29 (10), 1365-1378.

Benito, G. R. (2005). Divestment and international business strategy. Journal of Economic Geography, 5(2), 235-251.

Bernard, A. B., \& Jensen, J. B. (2007). Firm structure, multinationals, and manufacturing plant deaths. The Review of Economics and Statistics, 89(2), 193-204.

Berry, H. (2013). When do firms divest foreign operations? Organization Science, 24(1), 246-261.

Birkinshaw, J., Morrison, A., \& Hulland, J. (1995). Structural and competitive determinants of a global integration strategy. Strategic Management Journal, (8), 637.

Blake, D. J., \& Moschieri, C. (2017). Policy risk, strategic decisions and contagion effects: Firm-specific considerations. Strategic Management Journal, 38(3), 732-750.

Boddewyn, J. J. (1979). Foreign divestment: magnitude and factors. Journal of International Business Studies, 10(1), 21-26.

Brouthers, K. D., \& Hennart, J. F. (2007). Boundaries of the firm: Insights from international entry mode research. Journal of Management, 33(3), 395-425.

Caves, R. E. (2007). Multinational enterprise and economic analysis. Cambridge: Cambridge University Press.

Chang, S. J., \& Rhee, J. (2011). Rapid FDI expansion and firm performance. Journal of International Business Studies, 42, 979-994.

Chang, S. J., \& Singh, H. (1999). The impact of modes of entry and resource fit on modes of exit by multibusiness firms. Strategic Management Journal, 20(11), 1019-1035.

Chang, S. J. (1995). International expansion strategy of Japanese firms: Capability building through sequential entry. Academy of Management journal, 38(2), 383-407.

Chen, T. J., \& Wu, G. (1996). Determinants of divestment of FDI in Taiwan. Weltwirtschaftliches Archiv, 132(1), 172-184.

Chung, C. C., Lee, S. H., Beamish, P. W., Southam, C., \& Nam, D. D. (2013). Pitting real options theory against risk diversification theory: International diversification and joint ownership control in economic crisis. Journal of World Business, 48(1), $122-136$.
Chung, W., \& Song, J. (2004). Sequential investment, firm motives, and agglomeration of Japanese electronics firms in the United States. Journal of Economics and Management Strategy, 13(3), 539-560.

Cleves, M., Gould, W., \& Marchenko, Y. (2016). An Introduction to Survival Analysis Using Stata. Stata Press.

Collis, D. J. (1991). A resource-based analysis of global competition: The case of the bearings industry. Strategic Management Journal, 12, 49-68.

Coucke, K., \& Sleuwaegen, L. (2008). Offshoring as a survival strategy: evidence from manufacturing firms in Belgium. Journal of International Business Studies, 39(8), 1261-1277.

Dai, L., Eden, L., \& Beamish, P. W. (2017). Caught in the crossfire: Dimensions of vulnerability and foreign multinationals' exit from war-afflicted countries. Strategic Management Journal, 38(7), 1478-1498.

De Sousa, J., Mayer, T., \& Zignago, S. (2012). Market access in global and regional trade. Regional Science and Urban Economics, 42(6), 1037-1052.

Delios, A., \& Beamish, P. W. (1999). Geographic scope, product diversification, and the corporate performance of Japanese firms. Strategic Management Journal, 20(8), $711-727$.

Delios, A., \& Beamish, P. W. (2001). Survival and profitability: The roles of experience and intangible assets in foreign subsidiary performance, 44 pp. 1028-1038). Academy of Management journal.

Delios, A., \& Henisz, W. J. (2003). Political hazards, experience, and sequential entry strategies: The international expansion of Japanese firms, 1980-1998 Strategic management journal, 24(11), 1153-1164.

Dhanaraj, C., \& Beamish, P. W. (2004). Effect of equity ownership on the survival of international joint ventures. Strategic Management Journal, 25(3), 295-305.

Dörrenbächer, C., \& Gammelgaard, J. (2010). Multinational corporations, inter organizational networks and subsidiary charter removals. Journal of World Business, 45(3), 206-216.

Doukas, J. A., \& Lang, L. H. (2003). Foreign direct investment, diversification and firm performance. Journal of International Business Studies, 34(2), 153-172.

Doz, Y. (1987). International industries: Fragmentation versus globalization. Technology and Global Industry, 96-118.

Duhaime, I. M., \& Grant, J. H. (1984). Factors influencing divestment decision-making: Evidence from a field study. Strategic Management Journal, 5(4), 301-318.

Dunning, J. H. (1980). Toward an eclectic theory of international production: Some empirical tests. Journal of International Business Studies, 11(1), 9-31.

Dunning, J. H. (2009). Location and the multinational enterprise: a neglected factor? Journal of International Business Studies, 40(1), 5-19.

Fang, Y., Wade, M., Delios, A., \& Beamish, P. W. (2007). International diversification, subsidiary performance, and the mobility of knowledge resources. Strategic Management Journal, 28(10), 1053-1064.

Fang, Y., Wade, M., Delios, A., \& Beamish, P. W. (2013). An exploration of multinational enterprise knowledge resources and foreign subsidiary performance. Journal of World Business, 48(1), 30-38.

Gaur, A. S., \& Lu, J. W. (2007). Ownership Strategies and Survival of Foreign Subsidiaries: Impacts of Institutional Distance and Experience. Journal of Management, 33(10), 84-110.

Getachew, Y. S., \& Beamish, P. W. (2017). Foreign subsidiary exit from Africa: the effects of investment purpose diversity and orientation. Global Strategy Journal, 7(1), 58-82.

Ghoshal, S. (1987). Global strategy: An organizing framework. Strategic Management Journal, 8(5), 425-440.

Grant, R. M. (1991). The resource-based theory of competitive advantage. California Management Review, 33(3), 114-134.

Hannan, M. T. (1998). Rethinking age dependence in organizational mortality: Logical formalizations. American Journal of Sociology, 104(1), 126-164.

Hanson, G., Mataloni, R., \& Slaughter, M. (2005). Vertical Production Networks in Multinational Firms. Review of Economics and Statistics, 87(4), 664-678.

Harzing, A. W. (2000). An empirical analysis and extension of the Bartlett and Ghoshal typology of multinational companies. Journal of International Business Studies, 31(1), $101-120$.

Haynes, M., Thompson, S., \& Wright, M. (2003). The determinants of corporate divestment: evidence from a panel of UK firms. Journal of Economic Behavior and Organization, 52, 147-166.

Head, K., Ries, J., \& Swenson, D. (1995). Agglomeration benefits and location choice: evidence from Japanese manufacturing investments in the United States. Journal of International Economics, 38(3-4), 223-247.

Henisz, W. J., \& Delios, A. (2001). Uncertainty, imitation, and plant location: Japanese multinational corporations, 1990-1996 Administrative Science Quarterly, 46(3), 443-475.

Henisz, W. J. (2000). The institutional environment for multinational investment. The Journal of Law, Economics, and Organization, 16(2), 334-364.

Hennart, J. F. (2007). The theoretical rationale for a multinationality-performance relationship. Management International Review, 47(3), 423-452.

Hennart, J. F., Kim, D. J., \& Zeng, M. (1998). The impact of joint venture status on the longevity of Japanese stakes in US manufacturing affiliates. Organization Science, 9 (3), 382-395.

Hoetker, G. (2007). The use of logit and probit models in strategic management research: Critical issues. Strategic Management Journal, 28(4), 331-343.

Hood, N., \& Young, S. (1987). Inward investment and the EC: UK evidence on corporate integration strategies. JCMS: Journal of Common Market Studies, 26(2), 193-206.

Hultman, M., Robson, M. J., \& Katsikeas, C. S. (2009). Export product strategy fit and performance: An empirical investigation. Journal of International Marketing, 17(4), $1-23$.

Hummels, D. (1999). Have international transportation costs declined? Journal of International Economics, 54(1), 75-96. 
Iurkov, V., \& Benito, G. R. G. (2018). Change in domestic network centrality, uncertainty, and the foreign divestment decisions of firms. Journal of International Business Studies, 51(5), 788-812.

Jenkins, S. P. (1995). Easy estimation methods for discrete-time duration models. Oxford Bulletin of Economics and Statistics, 57(1), 129-136.

Johansson, J. K., \& Yip, G. S. (1994). Exploiting globalization potential: US and Japanese strategies. Strategic Management Journal, 15(8), 579-601.

Kim, H., Hoskisson, R. E., \& Lee, S. H. (2015). Why strategic factor markets matter: "New" multinationals' geographic diversification and firm profitability. Strategic Management Journal, 36(4), 518-536.

Kim, J. U., \& Aguilera, R. V. (2015). The World is Spiky: An Internationalization Framework for A Semi-Globalized World. Global Strategy Journal, 5(2), 113-132.

Kim, Y. C., Lu, J. W., \& Rhee, M. (2012). Learning from age difference: Interorganizational learning and survival in Japanese foreign subsidiaries. Journal of International Business Studies, 43(8), 719-745.

Konara, P., \& Ganotakis, P. (2020). Firm-specific resources and foreign divestments via selloffs: Value is in the eye of the beholder. Journal of Business Research, 110, 423-434.

Kobrin, S. J. (1991). An Empirical Analysis of the Determinants of Global Integration. Strategic Management Journal, 12(S1), 17-31.

Kogut, B. (1991). Joint ventures and the option to expand and acquire. Management Science, 37(1), 19-33.

Kogut, B., \& Kulatilaka, N. (1994). Operating flexibility, global manufacturing, and the option value of a multinational network. Management Science, 40(1), 123-139.

Krueger A.O. 1995. U.S. trade policy and the GATT review. In: Arndt S., Milner C. (eds.), The World Economy: Global Trade Policy, Blackwell: Oxford, U.K., 65-79.

Krugman, P. (1980). Scale economies, product differentiation, and the pattern of trade. The American Economic Review, 70(5), 950-959.

Leonard Barton, D. (1992). Core capabilities and core rigidities: A paradox in managing new product development. Strategic Management Journal, 13, 111-125.

Levitt, T. (1983). The globalization of markets. Harvard Business Review, 61(3), 92-102.

Li, J., \& Li, Y. (2010). Flexibility versus commitment: MNEs' ownership strategy in China. Journal of International Business Studies, 41(9), 1550-1571.

Li, J. (1995). Foreign entry and survival: Effects of strategic choices on performance in international markets. Strategic Management Journal, 16(5), 333-351.

Lu, J., \& Jiang, R. (2017). Too slow or too fast? Speed of FDI expansions, industry globalization, and firm performance. Long Range Planning, 50(1), 74-92.

Makino, S., \& Beamish, P. W. (1998). Performance and survival of joint ventures with non-conventional ownership structures. Journal of International Business Studies, 29 (4), 797-818.

Makino, S., Chan, C., Isobe, T., \& Beamish, P. (2007). Intended and unintended termination of international joint ventures. Strategic Management Journal, 28(1), 1113-1132.

Markides, C. C. (1992). Consequences of corporate refocusing: Ex ante evidence. Academy of Management Journal, 35(2), 398-412.

Mata, J., \& Portugal, P. (2000). Closure and divestiture by foreign entrants: The impact of entry and post-entry strategies. Strategic Management Journal, 21(5), 549-562.

McDermott, M. C. (2010). Foreign divestment: The neglected area of international business? International Studies of Management and Organization, 40(4), 37-53.

Melitz, M. J., \& Ottaviano, G. I. P. (2008). Market size, trade, and productivity. Review of Economic Studies, 75(1), 295-316.

Mion, G., \& Zhu, L. (2013). Import competition from and offshoring to China: A curse or blessing for firms? Journal of International Economics, 89(1), 202-215.

Morrison, A. J., \& Roth, K. (1992). A taxonomy of business-level strategies in global industries. Strategic Management Journal, 13(6), 399-417.

Nadkarni, S., Herrmann, P., \& Perez, P. D. (2011). Domestic mindsets and early international performance: The moderating effect of global industry conditions. Strategic Management Journal, 32(5), 510-531.
Nelson, R. R. (1991). Why do firms differ, and how does it matter? Strategic Management Journal, 12(S2), 61-74.

Nicita, A., \& Olarreaga, M. (2007). Trade, production, and protection database, 19762004 The World Bank Economic Review, 21(1), 165-171.

Norback, P.-J., Tekin-Koru, A., \& Waldkirch, A. (2015). Multinational firms and plant divestiture. Review of International Economics, 23(5), 811-845.

Ogasavara, M. H., \& Hoshino, Y. (2008). The effects of entry strategy and inter-firm trust on the survival of Japanese manufacturing subsidiaries in Brazil. Asian Business and Management, 7(3), 353-380.

Oviatt, B. M., \& McDougall, P. P. (1994). Toward a theory of international new ventures. Journal of International Business Studies, 25(1), 45-64.

Pennings, E., \& Sleuwaegen, L. (2000). International relocation: firm and industry determinants. Economics Letters, 67(2), 179-186.

Porter, M. E. (1986). Competition in global industries. Harvard Business Press.

Prahalad, C.K., Doz, Y.L. 1987. The multinational mission: Balancing global integration with local responsiveness. New York, NY.

Rangan, S. (1998). Do multinationals operate flexibly? Theory and evidence. Journal of International Business Studies, 29(2), 217-237.

Rugman, A., Verbeke, A., \& Yuan, W. (2011). Re-conceptualizing Bartlett and Ghoshal's classification of national subsidiary roles in the multinational enterprise. Journal of Management studies, 48(2), 253-277.

Schmid, S., \& Kotulla, T. (2011). 50 years of research on international standardization and adaptation-From a systematic literature analysis to a theoretical framework. International Business Review, 20(5), 491-507.

Schmid, D., \& Morschett, D. (2020). Decades of research on foreign subsidiary divestment: What do we really know about its antecedents? International Business Review, 29(4), 1-18.

Scott-Kennel, J., \& Giroud, A. (2015). MNEs and FSAs: Network knowledge, strategic orientation and performance. Journal of World Business, 50(1), 94-107.

Shaver, J. M., Mitchell, W., \& Yeung, B. (1997). The effect of own-firm and other-firm experience on foreign direct investment survival in the United States, 1987-92 Strategic Management Journal, 18(10), 811-824.

Short, J. C., Ketchen, D. J., Palmer, T. B., \& Hult, G. T. M. (2007). Firm, strategic group, and industry influences on performance. Strategic Management Journal, 28(2), $147-167$.

Song, S., \& Lee, J.-R. (2017). The hysteresis effects of investment relationships with headquarters on longevity of foreign subsidiaries. Management International Review, 57(4), 545-570.

Song, S. (2015). Exchange rate challenges, flexible intra-firm adjustments, and subsidiary longevity. Journal of World Business, 50(1), 36-45.

Soule, S. A., Swaminathan, A., \& Tihanyi, L. (2014). The diffusion of foreign divestment from Burma. Strategic Management Journal, 35(7), 1032-1052.

Tan, Q., \& Sousa, C. M. (2018). Performance and Business Relatedness as Drivers of Exit Decision: A Study of MNCs from an Emerging Country. Global Strategy Journal, 8(4), 612-634.

Teece, D. J., Pisano, G., \& Shuen, A. (1997). Dynamic Capabilities and Strategic Management. Strategic Management Journal, 18(7), 509-533.

Wiersema, M. F., \& Bowen, H. P. (2008). Corporate diversification: The impact of foreign competition, industry globalization, and product diversification. Strategic Management Journal, 29(2), 115-132.

Yip, G. S. (1989). Global strategy... in a world of nations? MIT Sloan Management Review, 31(1), 29-41.

Zaheer, S. (1995). Overcoming the liability of foreignness. Academy of Management Journal, 38(2), 341-363.

Zou, S., \& Cavusgil, S. T. (2002). The GMS: A broad conceptualization of global marketing strategy and its effect on firm performance. Journal of Marketing, 66(4), $40-56$. 